\title{
Premalignant Lesions and Conditions of the Oral Cavity
}

\author{
El Mustafa, Sat Parmar, and Prav Praveen
}

\subsection{Premalignant Lesions}

It is well established that oral cavity cancer develops in a two-step process and, consequently, that most malignant ulcers are preceded by a precursor lesions [1]. These lesions are typically red or white patches referred to altogether in the 2007 WHO consensus statement as the group of potentially malignant disorders (PMDs) [2] (Table 80.1). Clinical identification of PMDs offers a window for intervention: eliminating diseased mucosa and exclusion of occult invasive cancers. This is important from a clinician's perspective on several fronts. Firstly, it is important to be able to recognise high-risk lesions among a multitude of innocent oral conditions that present with similar features. Some conditions such as oral lichen plans may have a potential for malignant change, but the condition is so prevalent that it becomes impractical to monitor every single patient with the disease. To avoid additional burdens on clinical services, the oral physician or surgeon needs to make a decision as to which patients must be kept under review at a specialist centre and which may be safely referred back for ongoing follow-up in the community. Among those who are reviewed at a specialist practice, ongoing decisions are made at each visit, when to intervene and to what extent one should be aggressive with the treatment plan offered. On a second front are the difficulties of recognition of tumour recurrences following treatment. Surgical treatment and radiotherapy change the tissue appearance and texture irreversibly. Among these patients, it is known that a proportion would develop either a second tumour at the site of surgery or a new tumour in a neighbouring area. It is challenging enough to identify precancerous lesions in nascent tissue, and thus the clinician must be much more vigilant in recognising potentially cancerous new

E. Mustafa $\cdot$ S. Parmar $\cdot$ P. Praveen $(\bowtie)$

Department of Oral and Maxillofacial Surgery, Queen Elizabeth

Hospital, Birmingham, UK

e-mail: Prav.Praveen@uhb.nhs.uk
Table 80.1 Potentially malignant lesions

Potentially malignant lesions
Leukoplakia (idiopathic)
Proliferative verrucous leukoplakia
Erythroplakia
Oral submucous fibrosis
Oral lichen planus
Chronic hyperplastic candidosis

lesions in patients under follow-up posttreatment of head and neck cancer.

Further to these concerns, we know that premalignant conditions tend to develop in what is known as field change. This means that for any subsite within the oral cavity at which cellular nuclear damage resulted in a PMD (or even cancer), the adjacent mucosa is almost equally at risk of producing additional PMD lesions even if they appear normal to the naked eye.

Knowledge of the patterns and behaviour of PMDs (premalignant disorder) is thus an essential part of oral medicine and oral surgery practice.

The commonest PMDs are leukoplakia with an overall prevalence of $2.9 \%$ in the general population [3] and submucous fibrosis with a prevalence of nearly $11 \%$ in high-risk populations [4]. The risk for submucous fibrosis is specific to populations where paan use is prevalent unlike the risk for leukoplakia which is universally applicable. Lesions are considered potentially malignant rather than premalignant. Clinical behaviour is unpredictable; some lesions remain stable; others regress, but in up to $30 \%$ of cases, oral malignancy is diagnosed within 5 years of follow-up. Cancer may arise from the lesion itself or at a different subsite within the oral cavity reflecting the concept of 'field cancerisation' explained previously.

It is important to note that a role for primary prevention in patients with leukoplakia is not confirmed. For example, smoking is a risk factor for the development of leukoplakia, 
but smoking cessation does not necessarily reduce the risk of developing OCC. There is, however, benefit in screening for potentially malignant lesions, and this was demonstrated in a recent review of the US SEER-Medicare database of head and neck cancer. Yanik et al. [5] reported better treatment and survival outcomes in patients who developed oral cell carcinoma whilst under follow-up for a premalignant lesion [5]. This correlated with the fact that oral cancers were identified at an earlier stage in this patient cohort. Patients without the benefit of such close observation tended to present with more developed or advanced tumour forms. A role for screening patients following treatment for head and neck cancer recurrence is not known, and thus secondary prevention is not currently known to be effective. It is likely, however, that the principle of recognising early tumours and potentially malignant lesions would still result in timely provision of therapy. Table 80.1 enlists premalignant lesions discussed in this chapter.

\subsection{Aetiogenesis}

Development of a malignancy is a complex multistep process resulting from failures in several regulatory cellular pathways. Dysplasia in oral cancer is usually the first step in the malignant down spiral. Dysplasia is a descriptive term used on microscopic assessment. It indicates that the tissue has accrued a significant population of abnormal cells that display a pattern of nuclear damage that is known to herald cancerous behaviour. These changes are summarised in Table 80.2. Usually but not always, these changes are followed by unregulated hyperplasia (cellular multiplication). The tumour cells have gained autonomy meaning they escaped nuclear and immune mechanisms that limit excess growth and prevent accumulation of damaged cells. The final step is loss of integrity of the basement membrane at the boundary between mucosa and submucosa; the dysplastic cells begin to invade into the surrounding tissues or directly gain access to vascular channels. Each of these steps is controlled by molecular pathways directed by gatekeeper genes and gene products.

Two cellular or microscopic changes broadly define oral premalignancy: hyperplasia which results from over activation of the retinoblastoma pathway and the development of various degrees of dysplasia due to mutations in the p53

Table 80.2 Histological features of cellular dysplasia

Dysplastic changes
Irregular cell shape and orientation
Increased and abnormal mitoses
Nuclear pleomorphism
Coarse and clumped chromatin
Increased nuclear-to-cytoplasmic ratio
Prominent nucleoli
Dyskeratosis

Dysplastic change

Nuclear pleomorphism

Coarse and clumped chromatin

Prominent nucleol

Dyskeratosis gene. In health and normal physiology, genes along the retinoblastoma pathway activate transcription factors required for taking the cells from the indolent G1 to the active S phase. Overactivation of these genes leads to loss of control of orderly cell division resulting in epithelial hyperplasia. A product of the CDKN2A gene, the 16 protein, usually keeps this stage of cell cycle in check. This protein may become inactivated either because of a mutation/deletion/epigenetic slicing of the parent gene CDKN2A or through direct degradation by a viral product, the E7 protein, of the HPV virus (relevant to the development of oropharyngeal cancer). The retinoblastoma pathway may also be directly upregulated by amplification of the Cyclin D1 gene, a proto-oncogene of the locus 11q13 [6].

With each cell division, there is a probability of errors arising in the nuclear DNA resulting in a defective daughter cell. Most errors are corrected during cell division, or the cells are removed by immune mechanisms. Defective cells that have escaped these reparative measures may still be suppressed by transcription factors that induce apoptosis. Apoptosis is triggered through p53, a tumour suppressor protein. The protein $\mathrm{p} 14$ is an alternative reading frame of the CDKN2A gene responsible for initiating the p53 pathway. Direct degradation of p53 by the E6 viral protein (HPVrelated cancer) or genetic mutations in the parent gene (in $60 \%$ of non HPV cancer) restricts protective physiological apoptosis leading to a shift in cell population and accumulation of dysplastic cells. The premise behind looking out for premalignant disorders is that oral mucosa will change appearance with the onset of dysplastic changes and that the extent of dysplasia does correlate with malignant potential. High-grade dysplastic lesions indicate treatment is required imminently, whereas mild dysplastic lesions may be observed and are even considered a feature of benign chronic inflammation. Dysplasia is classified according to several grading systems summarised in Table 80.3, the most common system in use being the one proposed by the WHO in 2005. Further

Table 80.3 Grading systems for dysplasia

\begin{tabular}{|c|c|c|c|}
\hline Definition & WHO 2005 & $\begin{array}{l}\text { Ljubljana } \\
\text { system }\end{array}$ & $\begin{array}{l}\text { Equivalent SIN } \\
\text { (squamous } \\
\text { intra-epithelial } \\
\text { neoplasia) }\end{array}$ \\
\hline $\begin{array}{l}\text { Increase in the } \\
\text { number of normal } \\
\text { cells }\end{array}$ & $\begin{array}{l}\text { Squamous } \\
\text { cell } \\
\text { hyperplasia }\end{array}$ & $\begin{array}{l}\text { Squamous cell } \\
\text { (simple) } \\
\text { hyperplasia }\end{array}$ & \\
\hline $\begin{array}{l}\text { Atypical changes } \\
\text { confined to the } \\
\text { lower } 1 / 3 \text { of the } \\
\text { epithelium }\end{array}$ & $\begin{array}{l}\text { Mild } \\
\text { dysplasia }\end{array}$ & $\begin{array}{l}\text { Basal/ } \\
\text { parabasal cell } \\
\text { hyperplasia }\end{array}$ & SIN1 \\
\hline $\begin{array}{l}\text { Atypical changes } \\
\text { to the middle } 1 / 3 \\
\text { of the epithelium }\end{array}$ & $\begin{array}{l}\text { Moderate } \\
\text { dysplasia }\end{array}$ & $\begin{array}{l}\text { Atypical } \\
\text { hyperplasia }\end{array}$ & SIN2 \\
\hline $\begin{array}{l}\text { Changes involve } \\
\text { at least } 2 / 3 \text { of the } \\
\text { epithelium }\end{array}$ & $\begin{array}{l}\text { Severe } \\
\text { dysplasia }\end{array}$ & $\begin{array}{l}\text { Atypical } \\
\text { hyperplasia }\end{array}$ & SIN3 \\
\hline
\end{tabular}


genetic changes are involved in progression towards invasiveness, but these are not as well defined as these are outside the scope of the chapter.

\subsection{Leukoplakia}

Idiopathic leukoplakia is the most common premalignant disorder. Nearly one in every 10 cases of oral cavity cancer (OCC) is known to arise in leukoplakia (Fig. 80.1), usually within 3 months of diagnosis of the lesion [5]. These lesions are defined as 'white plaques of questionable risk having excluded disorders that carry no increased risk for cancer' [2]. Table 80.4 enlists white lesions without a known malignant potential. These are rare, and thus most persistent white patches are best treated with suspicion until further evaluation.

Clinical variants of leukoplakia include homogenous plaques, nodules, speckled erythroleukoplakia and a distinct subtype discussed separately: proliferative verrucous subtype. Leukoplakia is present in less than $1 \%$ of the general population [5] but with greater prevalence reported among those older than 75 years of age and tobacco users of all age groups [7]. Men are twice as much likely to develop leukoplakia compared with women. In the Indian subcontinent, in regions where betel is consumed, prevalence rates approach $5 \%$ [8]. The annual risk of malignant transformation is estimated between 1 and 2\% [9]. Larger non-homogeneous

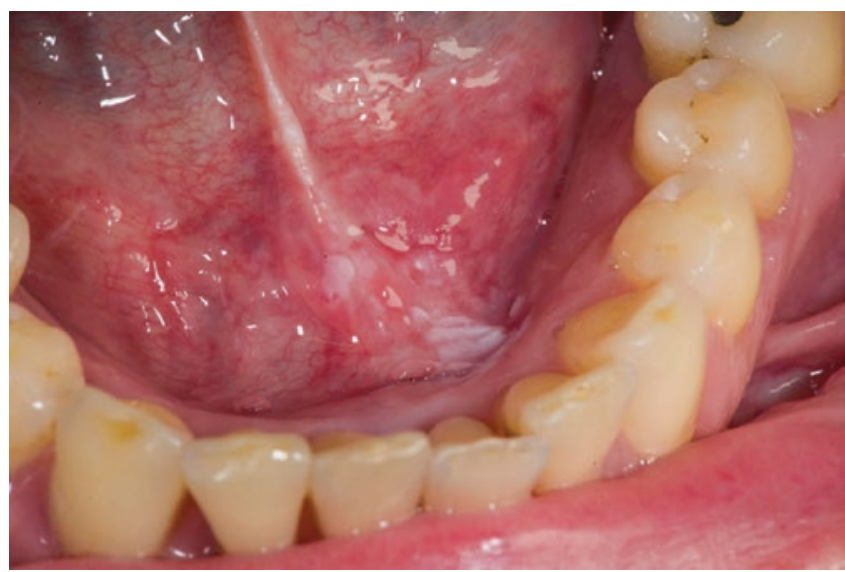

CAssociation of Oral and Maxillofacial Surgeons of India

Fig. $\mathbf{8 0 . 1}$ Leukoplakia

Table 80.4 Innocent white patches

\begin{tabular}{l|l|}
\hline \multicolumn{2}{l}{ White lesions not known to association with oral cancer } \\
\hline Developmental & Cannon white sponge nevus \\
\hline Metabolic & Uremic stomatitis \\
\hline Immune mediated & Benign migratory glossitis \\
\hline $\begin{array}{l}\text { Viral immune } \\
\text { suppression }\end{array}$ & Oral hairy leukoplakia associated with \\
\hline
\end{tabular}

Table 80.5 Risk predictors for malignant transformation

Risk factors for malignant transformation

\section{Duration}

Non-homogeneous type

Size $>200 \mathrm{~mm}$ squared

Site: Tongue, floor of the mouth

Leukoplakia in a non-smoker

Epithelial dysplasia

lesions, particularly those on the tongue and floor of the mouth, are associated with the highest conversion rates to oral squamous cell carcinoma. Table 80.5 lists clinical risk predictors for malignant transformation.

Tissue biopsy is required to assess the degree of epithelial dysplasia, an independent and consistently reliable risk factor for malignant transformation. Liu et al., using a binary grading of dysplasia, found that patients with high-risk lesions (moderate/severe dysplasia) eight times as likely to be diagnosed with oral cancer as those with low-risk (no/ mild dysplasia) lesions [10]. Histological evaluation may also identify other conditions that are clinically indistinguishable from idiopathic leukoplakia such as hyperplastic candidosis, oral lichen planus variants, lichenoid reactions and discoid lupus.

Categorisation into high- and low-risk lesions is helpful in identifying target areas for surgical removal and those that may be safely observed but closely followed up.

However, in populations with high incidence of oral cancer, studies have shown oral leukoplakia as foci of invasive cancer and have advocated surgical excision of these lesions.

Toluidine blue dye improves visual detection of highrisk mucosa [11] and helps determine the extent of peripheral margins required for complete excision. It is not established whether surgical intervention reduces the risk of subsequent cancer, but a resection specimen may upgrade the histological evaluation or identify areas of occult focal invasion. Recurrence following surgery is observed in $10 \%$ of cases [12]. Laser surgery is effective in controlling lowgrade leukoplakia, but significantly higher failure rates of up to $9 \%$ were reported in high-grade lesions and erythroleukoplakia [13]. Recent reviews have examined photodynamic therapy as a treatment option particularly helpful in controlling widespread and multifocal leukoplakia [14]. Partial and complete response rates as high as 70-100\% were reported, but the range of photosensitisers used and photo-irradiation protocols applied varied greatly between individual authors.

Medical treatments for oral premalignancy include systemic vitamin A, systemic beta carotene and topical bleomycin. These were shown to control premalignant lesions, but a 2016 Cochrane review concluded that relapse rates were high and that transformation into oral cancer was not effectively reduced [15]. 


\subsection{Proliferative Verrucous Leukoplakia}

Proliferative verrucous leukoplakia (PVL) is a distinct and aggressive form of leukoplakia with one of the highest known malignant transformation rates. It is typically diagnosed in elderly women (4:1 female ration) without a history of tobacco use [16]. Aetiology is thus largely unknown. Lesions often start as isolated flat white plaques but gradually spread to become diffuse and multifocal with a characteristic warty appearance (Fig. 80.2). There typically is no erosive component. The lesions tend to present on the tongue or buccal mucosa or well as the alveolar ridge. They can be mistaken for hyperplastic candidosis or frictional keratosis particularly in denture wearers. Histological appearance is dependent on the stage of the disease ranging from benign hyperkeratosis to dysplastic keratosis merging into verrucous carcinoma. Malignant transformation may also happen simultaneously at multiple foci, and this is one of the clearest manifestations of the field cancerisation concept introduced earlier. Verrucous carcinoma is a squamous cancer with welldifferentiated histopathological architecture that displays very little cellular atypia.

PVL is a lesion that benefits from excision biopsy rather than an incisional sample (see biopsy discussion below) for it is estimated that $20 \%$ of verrucous lesions, if adequately sampled, would reveal foci of conventional pattern squamous cell carcinoma. Local control is, however, difficult with high recurrence rates following surgical excision and greater malignant transformation rates in excess of $70 \%$ [17]. It is also one of the most difficult lesions to follow up, requiring multiple biopsies to monitor behaviour over time.

\subsection{Erythroplakia}

Erythroplastic lesions (Fig. 80.3) are similarly defined to oral leukoplakia but as red velvety lesions following exclusion of other named entities. It is a rare disorder with prevalence

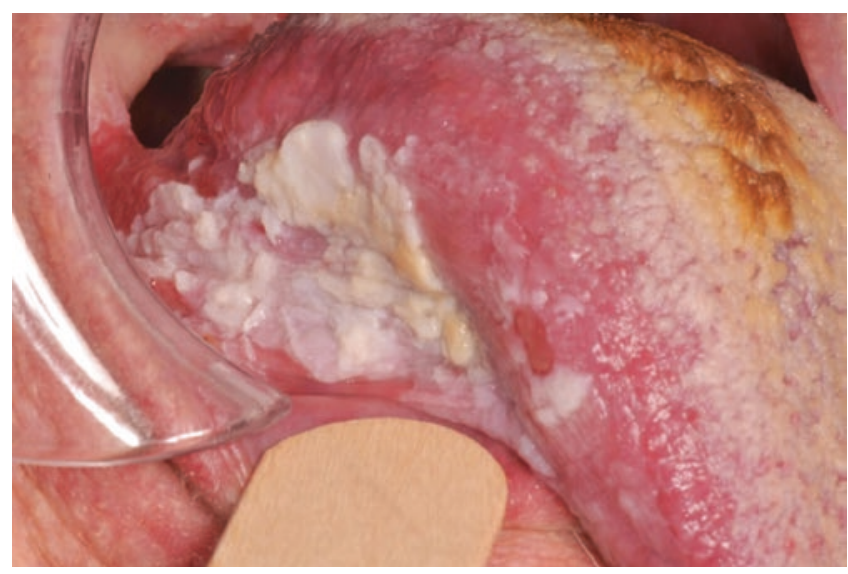

CAssociation of Oral and Maxillofacial Surgeons of India

Fig. 80.2 Proliferative verrucous leukoplakia

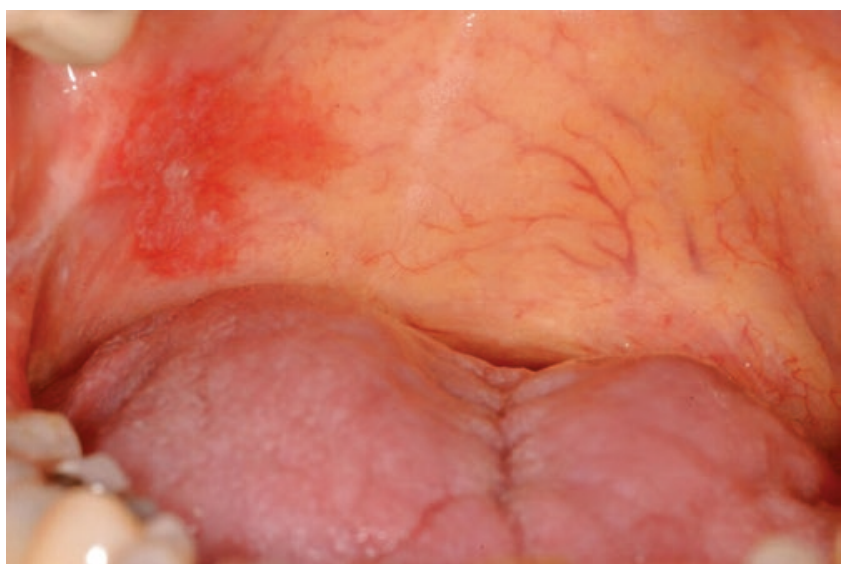

CAssociation of Oral and Maxillofacial Surgeons of India

Fig. 80.3 Erythroplakia

between 0.01 and $0.2 \%$ but a much higher transformation rate compared to leukoplakia, reportedly between 51 and $90 \%$ [16]. Clinical appearance tends to follow one of three patterns: the homogenous, granular and speckled types [12]. Most common subsides are the palate, the buccal mucosa and the floor of the mouth. Lesions are rarely multicentric and may present a similar clinical appearance to erosive and atrophic oral lichen planus, erythema migrans, stomatitis, candidosis, lymphatic malformations and desquamative gingivitis (e.g. vesiculobullous lesions and gingival lichen planus). Speckled erythroplakia and leukoplakia most likely refer to the same disorder with red appearance correlating to highrisk epithelial dysplasia. Treatment options are surgical excision, laser excision or evaporation as per leukoplakia with a lower threshold for application for wide local excision due to the higher risk of cancer development.

\subsection{Submucous Fibrosis}

Oral submucous fibrosis is progressive scarring disorder linked to the use of betel products (paan). Additional risk for oral squamous cell carcinoma is conferred by the addition of slaked lime to the betel quid or concurrent use of tobacco. The active ingredients in paan include arecoline, copper and polyphenol fragments (flavonols, tannins) which stimulate an intense acute inflammatory response characterised by a polymorphic infiltrate and vascular dilatation. This gives way to a chronic immune response and constrictive vascular changes that end with obliteration of blood vessels in the affected region. Over time, this leads to an epithelial to mesenchymal transition mediated by TGF- $\beta$ [18]. Fibroblasts are activated, and collagen is deposited steadily replacing the submucous tissues with hyalinised cartilage almost devoid of cellular components. Several genes are known to associate with the risk of developing submucous fibrosis including MMP3 gene promoter region and CYP1A1/CYP2E1 genes, 
Table 80.6 Histopathological changes in submucous fibrosis

\begin{tabular}{|c|c|c|c|}
\hline $\begin{array}{l}\text { Very early } \\
\text { Stage I }\end{array}$ & Early Stage II & $\begin{array}{l}\text { Moderate } \\
\text { advanced Stage } \\
\text { III }\end{array}$ & $\begin{array}{l}\text { Advanced } \\
\text { Stage IV }\end{array}$ \\
\hline $\begin{array}{l}\text { Fine fibrillar } \\
\text { collagen and } \\
\text { marked } \\
\text { oedema. }\end{array}$ & $\begin{array}{l}\text { - Early } \\
\text { junta- } \\
\text { epithelial } \\
\text { hyalinisation }\end{array}$ & $\begin{array}{l}\text { - Moderately } \\
\text { hyalinised } \\
\text { collagen. }\end{array}$ & $\begin{array}{l}\text { - Completely } \\
\text { hyalinised } \\
\text { collagen. }\end{array}$ \\
\hline $\begin{array}{l}\text { - Strong } \\
\text { fibroblastic } \\
\text { response. }\end{array}$ & $\begin{array}{l}\text { - Moderate } \\
\text { fibroblastic } \\
\text { response. }\end{array}$ & $\begin{array}{l}\text { - Predominantly } \\
\text { fibrocytes, } \\
\text { reduced } \\
\text { fibroblasts. }\end{array}$ & $\begin{array}{l}\text { Hyalinised } \\
\text { collagen } \\
\text { devoid of } \\
\text { fibroblasts. }\end{array}$ \\
\hline $\begin{array}{l}\text { - Acute } \\
\text { polymorphic } \\
\text { inflammatory } \\
\text { cell infiltrate. }\end{array}$ & $\begin{array}{l}\text { - Mononuclear } \\
\text { and } \\
\text { lymphocytic } \\
\text { inflammatory } \\
\text { cell infiltrate. }\end{array}$ & $\begin{array}{l}\text { - Lymphocytic } \\
\text { and plasma } \\
\text { cell } \\
\text { inflammatory } \\
\text { cell infiltrate. }\end{array}$ & $\begin{array}{l}\text { - Lymphocytic } \\
\text { and plasma } \\
\text { cell } \\
\text { inflammatory } \\
\text { cell infiltrate. }\end{array}$ \\
\hline $\begin{array}{l}\text { - Normal or } \\
\text { dilated- } \\
\text { congested } \\
\text { blood } \\
\text { vessels. }\end{array}$ & $\begin{array}{l}\text { - Dilated- } \\
\text { congested } \\
\text { blood vessels. }\end{array}$ & $\begin{array}{l}\text { - Normal to } \\
\text { constricted } \\
\text { vessels. }\end{array}$ & $\begin{array}{l}\text { - Markedly } \\
\text { constricted or } \\
\text { completely } \\
\text { obliterated } \\
\text { blood vessels }\end{array}$ \\
\hline
\end{tabular}

but the genetic basis for transformation into squamous cell carcinoma is not currently defined. Table 80.6 summarised the histopathological evolution and progression of submucous fibrosis.

Consumption of paan is common in Southeast Asia and the Western Pacific but is now also seen in Europe and North America. It is estimated that more than half a billion persons consume betel worldwide [19]. Early presentation reflects the early histological picture with non-specific inflammatory mucosal changes. The diagnosis becomes clearer when early changes are replaced by the characteristic hypo-vascular blanched appearance with a fibrous texture although these changes may be patchy or reticular causing potential confusion with unrelated mucosal changes (e.g. lichen planus). In general, submucous fibrosis tends to present in young adults (predominantly males) with worsening trismus $(37.2 \%$ of patients), painful dysesthesia (25.9\%), excess salivation (22.5\% of patients) and recurrent ulceration. Clinical findings on examination are white patches particularly in the buccal mucosa $(20.8 \%)$ and the palate $(17.7 \%)$ followed by the floor of mouth and the retromolar trigone [20]. Clinical signs develop within 3-5 years following commencement of chewing betel preparations. Patients are 19 times as likely to develop oral cancer particularly with betel quid containing tobacco [4]. Malignant transformation rates are reportedly $4-13 \%$ [21].

Conservative and medical measures are considered for the early clinical stages. This includes physiotherapy, immune modulators steroids and promoters of blood flow such as pentoxifylline. Many other medical treatments are reported but none with definitive clinical benefit.

Surgical options are limited and complete excision unlikely, but surgery is usually indicated for local release of

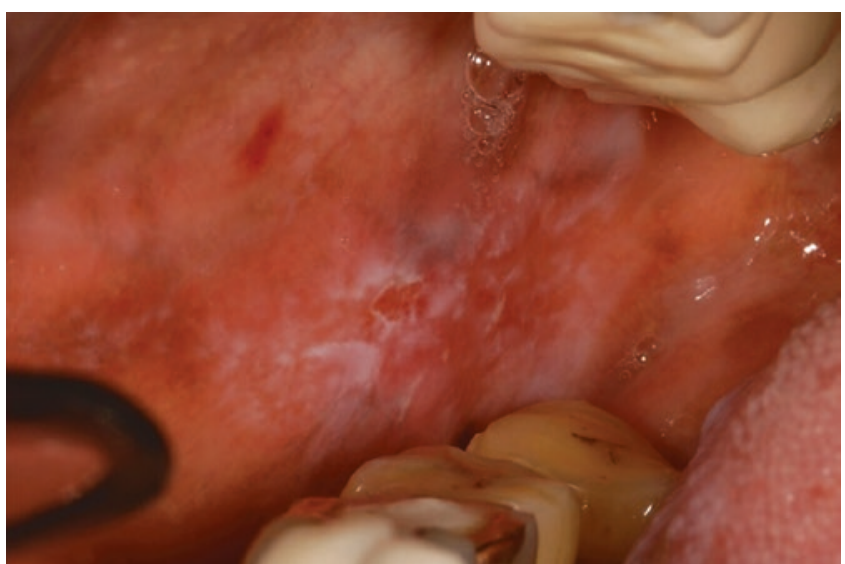

CAssociation of Oral and Maxillofacial Surgeons of India

Fig. 80.4 Oral lichen planus

retromolar or buccal scarring to help relieve trismus. Release of trismus is usually necessary at the mouth opening of $25 \mathrm{~mm}$ and less and is achieved with incisions, local $\mathrm{V}-\mathrm{Y}$ flaps and masticator muscle myotomy, resurfacing the defect with the buccal fat pad or other grafts.

\subsection{Oral Lichen Planus}

Lichen planus (LP) (Fig. 80.4) is a prevalent inflammatory much cutaneous disease affecting $5 \%$ of the population worldwide. The pathogenesis is not well understood but is essentially an autoimmune response to the epidermal basal cell layer mediated by cytotoxic $\mathrm{T}$ cells. Characteristically, $\mathrm{T}$ cells are seen to infiltrate into the lamina propria on microscopy and the damaged basal keratinocytes degrade into apoptotic residues known as civatte bodies (not pathognomonic for LP) [22]. Aetiology is unknown, but it is well recognised that appearances of lichen plans can result from a hypersensitivity reaction to nonsteroidal anti-inflammatories, angiotensin-converting enzyme inhibitors and dental amalgam. These reactions are more commonly referred to as lichenoid mucositis. In rare instances, the disease associates with viral hepatitis (B and C), but in most patients LP, there is no triggering factor. Stress is thought to be a contributing factor.

Commonly, oral lichen planus (OLP) presents as reticular white patterns on the buccal mucosa or the tongue known as Wickham's striae. Many varieties and presentations are recognised such as desquamative gingivitis, plaque form and an unusual form that presents with vesicular bullae. An erosive form is also recognised giving the appearance of the highrisk erythroplakia and mixed red and white lesions [23]. Some authors use the term erosive OLP to refer to the ulcerated type of lesion and erythematous OLP as the commoner type which affects atrophied buccal mucosa (usually seen 
with reticular lesions). Distribution is usually symmetrical, a feature it shares with discoid lupus.

It is not clear whether oral lichen planus (OLP), a relatively common benign condition, is an independent risk factor for malignancy. A meta-analysis of 7806 patients concluded that just over $1 \%$ of patients OLP develop oral cavity cancer [24]. The highest risk subsites were predominantly the tongue $(51 \%)$ and the buccal mucosa $(32 \%)$. Malignant transformation was three times as likely in females as it was in men. It is proposed that changes at lower-power magnification of oral leukoplakia resemble lichen planus or that lichenoid changes in epithelial dysplasia are common. Clinically, there is overlap between the clinical appearance of the various types of OLP and between erythroleukoplakia and verrucous leukoplakia. A diagnosis of OLP is more likely in symmetric lesions, but only a biopsy demonstrating epithelial dysplasia would confirm truly high-risk lesions. Correlation between malignant change and certain subtypes of OLP, namely, the erosive and plaque-like forms, has not been consistent. Interestingly a co-existence with proliferative verrucous leukoplakia has been noted by several authors $[25,26]$.

\subsection{Chronic Hyperplastic Candidosis}

Candida is present in the oral cavity in between 40 and $60 \%$ of healthy individuals. Association between Candida infection and cancer is through smoking, an independent risk factor equally for the development of chronic hyperplastic candidosis (CHC) and premalignant mucosal lesions. Once hyperplastic candidosis is established, these lesions manifest and behave similar to homogeneous or speckled leukoplakia with $15 \%$ risk of progression to epithelial dysplasia [27]. $\mathrm{CHC}$ is usually resistant to antifungal therapy, and thus surgery is indicated particularly for well-defined lesions.

\subsection{Premalignant Conditions}

Premalignant conditions are a disparate group of rare congenital and acquired disorders of immune regulation, inheritable genetic instability and infectious diseases. Table 80.7 enlists conditions that associate with mucosal SCC followed by Table 80.8 which also provides a summary of clinical features, site distribution and risk probabilities for conditions that associate with the cutaneous type of squamous carcinoma. Reports of malignant transformations are generally few and data concerning the natural history of OCC limited. Conditions that rarely associate with oral SCC such as Plummer-Vinson syndrome are not discussed here.
Table 80.7 Potentially malignant conditions: mucosal SCC

\begin{tabular}{|c|c|c|}
\hline $\begin{array}{l}\text { Potentially } \\
\text { malignant } \\
\text { conditions: mucosal } \\
\text { SCC }\end{array}$ & Aetiology & Clinical characteristics \\
\hline $\begin{array}{l}\text { Dyskeratosis } \\
\text { congenita } \\
\text { (mucocutaneous } \\
\text { variant) [28] }\end{array}$ & $\begin{array}{l}\text { Multigene defects, } \\
\text { telomere } \\
\text { dysfunction and } \\
\text { bone marrow } \\
\text { failure. } \\
\text { Sporadic de novo, } \\
\text { autosomal } \\
\text { dominant and } \\
\text { X-linked recessive } \\
\text { types }\end{array}$ & $\begin{array}{l}\text { Triad: Nail dystrophy, } \\
\text { reticular skin } \\
\text { pigmentation, oral } \\
\text { leukoplakia. } \\
\text { Oral leukoplakia in } 80 \% \\
\text { of patients. 40-5\% } \\
\text { malignant transformation } \\
\text { into SCC }\end{array}$ \\
\hline Syphilis & $\begin{array}{l}\text { Spirochete } \\
\text { infection }\end{array}$ & $\begin{array}{l}\text { Verrucous type and } \\
\text { speckled leukoplakia in } \\
\text { tertiary syphilis. Usually } \\
\text { in the lips, tongue or } \\
\text { palate. } 3-33 \% \text { risk of } \\
\text { transformation }\end{array}$ \\
\hline $\begin{array}{l}\text { Graft versus host } \\
\text { disease }\end{array}$ & $\begin{array}{l}\text { Complication of } \\
\text { allogenic stem cell } \\
\text { transplantation }\end{array}$ & $\begin{array}{l}\text { Oral lichenoid, erosions } \\
\text { and painful ulcers. Few } \\
\text { case reports of cancer } \\
\text { transformation }\end{array}$ \\
\hline $\begin{array}{l}\text { Acquired immune } \\
\text { deficiency } \\
\text { syndrome [29] }\end{array}$ & HIV virus & $\begin{array}{l}\text { HPV positive } \\
\text { oropharyngeal } \\
\text { SCC. Kaposi sarcoma }\end{array}$ \\
\hline
\end{tabular}

Table 80.8 Potentially malignant conditions: cutaneous SCC

\begin{tabular}{l|l|l|}
$\begin{array}{l}\text { Potentially } \\
\text { malignant } \\
\text { conditions: } \\
\text { cutaneous SCC }\end{array}$ & $\begin{array}{l}\text { Aetiology } \\
\text { Actinic cheilitis }\end{array}$ & $\begin{array}{l}\text { Solar radiation } \\
\text { Clinical characteristics }\end{array}$ \\
$\begin{array}{l}\text { Diffuse, atrophic, ulcerative or } \\
\text { keratotic patches in the lower } \\
\text { lip. 6\% risk of malignant } \\
\text { transformation }\end{array}$ \\
\hline $\begin{array}{l}\text { Xeroderma } \\
\text { pigmentosum }\end{array}$ & $\begin{array}{l}\text { Autosomal } \\
\text { recessive } \\
\text { inheritance }\end{array}$ & $\begin{array}{l}\text { Cutaneous-type SCC on the } \\
\text { lower lip observed in young } \\
\text { adults, age <20 years }\end{array}$ \\
\hline $\begin{array}{l}\text { Discoid Lupus [30] } \\
\text { 1.3-6.5\% risk of developing } \\
\text { SCC and BCC with lighter } \\
\text { skin. } \\
\text { Risk increased to 22\% in } \\
\text { discoid lesions. }\end{array}$ \\
\hline $\begin{array}{l}\text { Locally aggressive lesions } \\
\text { with high recurrence rates }\end{array}$
\end{tabular}

\subsection{Tissue Biopsy}

A sample of tissue is required whenever a premalignant disorder is suspected. Dysplasia cannot be visualised on clinical inspection. It is true that some lesions such as the speckled red and white lesions are most likely to harbour dysplastic cells, but it is hard to characterise white patches as dysplastic or not on clinical examination alone. Most sites within the oral cavity are accessible for a biopsy under 
local anaesthetic. General anaesthetic may well be indicated in some cases depending on tumour site particularly in the oropharynx or in patients not compliant with awake procedures. A biopsy may be obtained either by using a scalpel blade or through a punch biopsy applicator with pre-set width.

A small amount of local anaesthetic is administered locally within the site of the lesion for it provides pain relief and vasoconstriction through the action of an additive. Concentrations of 1:50,000 to 1:200,000 epinephrine are used as vasoconstrictor additives typically to lidocaine. Other vasoconstrictor agents include felypressin typically combined with prilocaine as a local anaesthetic. Care should be taken in patients who take anti-platelets agents or anticoagulant medications. The oral mucosa has a rich blood supply, and bleeding from small biopsy sites may prove to be difficult to control.

Excision of the abnormal patch as a whole may be achievable in smaller lesions, but in large and extensive lesions, an incisional sample is indicated. The site for taking a biopsy in this case is important. A white lesion may contain within multiple foci, and a biopsy from a uniform looking area may miss an area of dysplasia or early invasive cancers. Within a white lesion, it is advisable to take a biopsy from a speckled area, an area where there is induration/thickening and an erosive patch or where there is frank ulceration. When there is ulceration, then removal of tissue from the centre of the ulcer may return tissue that is necrotic and hard for the pathologist to interpret. Thus, it is also advised to take a biopsy from the margin of the ulcer particularly if the margin is elevated or everted. A small extension to incorporate normal looking tissue is helpful to enable the pathologist to visualise pathological transition into normal background architecture and pick up subtle changes that may otherwise be difficult to interpret.

The full thickness of mucosa is required for complete assessment. Invasiveness is impossible to interpret without inclusion of the basement membrane in the tissue biopsy. Traditionally that may not have been crucial for at the highest end of the dysplastic spectrum severe dysplasia is also considered to be at least as intra-epithelial neoplasia and in most cases surgical excision would be indicated. However, recent modifications of the TNM classification system and the work of D'Cruz et al. have highlighted depth of invasion as an independent risk predictor for regional metastasis [31].

Thus a biopsy may not only identify the nature of the lesion and reveal unexpected invasiveness; it may also determine the next step in treatment whether surgical excision of the lesion is enough or whether the threshold for regional surgery (i.e. a neck dissection) is required as well.

Once the sample is removed, haemostasis is required with either bipolar diathermy or, in small sites, chemical cautery with silver nitrate that is useful too. Most biopsy sites lend themselves to primary closure with a resorbable suture, whereas particular sites such as the mucosa overlying the hard palate may be safely left to heal by secondary intent.

\subsection{Conclusion}

Clinical examination of the oral cavity must include active screening for mucosal changes that are potentially cancerous. This may take place in the primary care setting, in dental practice, for these lesions are mostly asymptomatic and the patients may not be aware of their presence. A high index of suspicion is required for it is well known that although some lesions associate with known risk factors (e.g. oral submucous fibrosis), many lesions do not (e.g. verrucous leukoplakia). Clinical features may be ambiguous with some lesions that are red, erosive or speckled lending themselves to easier recognition compared with faint leukoplakia and subtle early changes in long-standing lichen planus. A low threshold for biopsy is recommended unless the lesion is demonstrably consistent with candidosis (i.e. may be clinically wiped off) or in the case of striated lichen planus that has remained consistent and well defined. Clinical photography is helpful in establishing objective documentation lesions for it is likely that the patient would be reviewed by different clinicians during follow-up. Once identified and histology is characterised, then lesions require stratification into high-risk and low-risk categories in order to determine the long-term plan for the patients, namely, surgical removal versus clinical observation, and the appropriate recall intervals for future follow-up. As discussed above, the treatment options are diverse and are tailored to the size of the lesion and degree of epithelial dysplasia. Although surgical removal does not eliminate the risk of malignant change entirely, early identification and close follow-up of premalignant lesions offer the best chance for achievement of good local control if and when oral cancer develops.

\section{References}

1. Reibel J. Prognosis of Oral pre-malignant lesions: significance of clinical, histopathological, and molecular biological characteristics. Crit Rev Oral Biol Med. 2003;14:47-62.

2. Warnakulasuriya S, Johnson NW, van der Waal I. Nomenclature and classification of potentially malignant disorders of the oral mucosa. J Oral Pathol Med. 2007;36(10):575-80.

3. Bánóczy J, Gintner Z, Dombi C. Tobacco use and oral leukoplakia. J Dent Educ. 2001;65(4):322-7.

4. Wollina U, Verma SB, Ali FM, Patil K. Oral submucous fibrosis: an update. Clin Cosmet Investig Dermatol. 2015;8:193-204.

5. Yanik EL, Katki HA, Silverberg MJ, Manos MM, Engels EA, Chaturvedi AK. Leukoplakia, oral cavity cancer risk, and cancer survival in the U.S. elderly. Cancer Prev Res (Phila). 2015;8(9):857-63. 
6. Pitiyage G, Tilakaratne WM, Tavassoli M, Warnakulasuriya S. Molecular markers in oral epithelial dysplasia: review. J Oral Pathol Med. 2009;38(10):737-52.

7. Amagasa T. Oral premalignant lesions. Int Clin Oncol. 2011;16:1-4.

8. Gupta PC, Mehta FS, Daftary DK, Pindborg JJ, Bhonsle RB, Jalnawalla PN, et al. Incidence of oral cancer and natural history of oral precancerous lesions in a 10-year follow-up study of Indian villagers. Community Dent Oral Epidemiol. 1980;8:283-333.

9. Brouns ER, Baart JA, Bloemena E, Karagozoglu H, van der Waal I. The relevance of uniform reporting in oral leukoplakia: definition, certainty factor and staging based on experience with 275 patients. Med Oral Patol Oral Cir Bucal. 2012;18(1):e19-26.

10. Liu W, Wang YF, Zhou HW, Shi P, Zhou ZT, Tang GY. Malignant transformation of oral leukoplakia: a retrospective cohort study of 218 Chinese patients. BMC Cancer. 2010;10:685.

11. Chainani-Wu N, Madden E, Cox D, Sroussi H, Epstein J, Silverman $\mathrm{S}$ Jr. Toluidine blue aids in detection of dysplasia and carcinoma in suspicious oral lesions. Oral Dis. 2015;21(7):879-85.

12. Lodi G, Porter S. Management of potentially malignant disorders: evidence and critique. J Oral Pathol Med. 2008;37:63-9.

13. Thomson PJ, Goodson ML, Cocks K, Turner JE. Interventional laser surgery for oral potentially malignant disorders: a longitudinal patient cohort study. Int J Oral Maxillofac Surg. 2017;46(3):337-42.

14. Gondivkar SM, Gadbail AR, Choudhary MG, Vedpathak PR, Likhitkar MS. Photodynamic treatment outcomes of potentiallymalignant lesions and malignancies of the head and neck region: A systematic review. J Investig Clin Dent. 2018;9(1)

15. Lodi G, Franchini R, Warnakulasuriya S, Varoni E, Sardella A, Kerr AR, Carrassi A, MacDonald LCI, Worthington HV. Interventions for treating oral leukoplakia to prevent oral cancer. Cochrane Database Syst Rev. 2016;7(7):CD001829.

16. Mortazavi H, Baharvand M, Mehdipour M. Oral potentially malignant disorders: an overview of more than 20 entities. J Dent Res Dent Clin Dent Prospects. 2014;8(1):6-14.

17. Munde A, Karle R. Proliferative verrucous leukoplakia: an update. J Cancer Res Ther. 2016;12(2):469-73.

18. Hu Y, Jian X, Peng J, Jiang X, Li N, Zhou S. Gene expression profiling of oral submucous fibrosis using oligonucleotide microarray. Oncol Rep. 2008;20(2):287-94.
19. Nelson BS, Heischober B. Betel nut: a common drug used by naturalized citizens from India, Far East Asia, and the South Pacific Islands. Ann Emerg Med. 1999;34(2):238-43.

20. Pandya S, Chaudhary AK, Singh M, Singh M, Mehrotra R. Correlation of histopathological diagnosis with habits and clinical findings in oral submucous fibrosis. Head Neck Oncol. 2009; $1: 10$

21. Yaming P, Urs AB, Saxena A, Zuberi M. Roles of CYP1A1 and CYP2E1 gene polymorphisms in Oral submucous fibrosis. Asian Pac J Cancer Prev. 2016;17(7):3335-40.

22. Pranay T, Kumar AS, Chhabra S. Civatte bodies: a diagnostic clue. Indian J Dermatol. 2013;58(4):327.

23. Olson MA, Rogers RS 3rd, Bruce AJ. Oral lichen planus. Clin Dermatol. 2016;34(4):495-504.

24. Fitzpatrick SG, Hirsch SA, Gordon SC. The malignant transformation of oral lichen planus and oral lichenoid lesions: a systematic review. J Am Dent Assoc. 2014;145:45-56.

25. Lopes MA, Feio P, Santos-Silva AR, Vargas PA. Proliferative verrucous leukoplakia may initially mimic lichenoid reactions. World J Clin Cases. 2015;3(10):861-3.

26. Garcia-Pola MJ, Llorente-Pendás S, González-Garcia M, GarcíaMartín JM. The development of proliferative verrucous leukoplakia in oral lichen planus. A preliminary study. Med Oral Patol Oral Cir Bucal. 2016;21(3):e328-34.

27. Shah N, Ray JG, Kundu S, Sardana D. Surgical management of chronic hyperplastic candidiasis refractory to systemic antifungal treatment. J Lab Physicians. 2017;9(2):136-9.

28. Alter BP, Giri N, Savage SA, Rosenberg PS. Cancer in dyskeratosis congenita. Blood. 2009;113(26):6549-57.

29. McLemore MS, Haigentz M, Smith RV, et al. Head and neck squamous cell carcinomas in HIV-positive patients: a preliminary investigation of viral associations. Head Neck Pathol. 2010;4(2):97-105.

30. Bhat MR, Hulmani M, Dandakeri S, Kambil SM, Gatti R. Disseminated discoid lupus erythematosus leading to squamous cell carcinoma. Indian J Dermatol. 2012;57(2):158-61.

31. D'Cruz AK, Vaish R, Kapre N, Dandekar M, Gupta S, Hawaldar $\mathrm{R}$, et al. Head and neck disease management group. Elective versus therapeutic neck dissection in node-negative oral cancer. N Engl J Med. 2015 Aug 6;373(6):521-9.

Open Access This chapter is licensed under the terms of the Creative Commons Attribution 4.0 International License (http://creativecommons. org/licenses/by/4.0/), which permits use, sharing, adaptation, distribution and reproduction in any medium or format, as long as you give appropriate credit to the original author(s) and the source, provide a link to the Creative Commons license and indicate if changes were made.

The images or other third party material in this chapter are included in the chapter's Creative Commons license, unless indicated otherwise in a credit line to the material. If material is not included in the chapter's Creative Commons license and your intended use is not permitted by statutory regulation or exceeds the permitted use, you will need to obtain permission directly from the copyright holder. 